\title{
Tree Community Composition and Dispersal Syndrome Vary with Human Disturbance in Sacred Church Forests in Ethiopia
}

\author{
Carrie L. Woods ${ }^{1, *(\mathbb{D})}$, Amare Bitew Mekonnen ${ }^{2}\left(\mathbb{D}\right.$, Mabel Baez-Schon $\left.{ }^{3}{ }^{(}\right)$, Robyn Thomas ${ }^{1}$, \\ Peter Scull ${ }^{4}$, Berhanu Abraha Tsegay ${ }^{2}\left(\mathbb{D}\right.$ and Catherine L. Cardelús ${ }^{5}$ \\ 1 Department of Biology, University of Puget Sound, Tacoma, WA 98406, USA; rthomas0415@gmail.com \\ 2 Department of Biology, Bahir Dar University, Bahir Dar 6000, Ethiopia; amarebitew8@gmail.com (A.B.M.); \\ berhanu.tsegay@gmail.com (B.A.T.) \\ 3 School of Forest Resources and Conservation, University of Florida, Gainesville, FL 32611, USA; \\ mabelbaez@ulf.edu \\ 4 Department of Geography, Colgate University, Hamilton, NY 13346, USA; pscull@colgate.edu \\ 5 Department of Biology, Colgate University, Hamilton, NY 13346, USA; ccardelus@colgate.edu \\ * Correspondence: cwoods@pugetsound.edu; Tel.: +01-253-879-3301
}

Received: 6 September 2020; Accepted: 5 October 2020; Published: 10 October 2020

\begin{abstract}
Research Highlights: Variations in species composition across church forests in northern Ethiopia were driven more by variations in human disturbance and community forest management than forest size. The degree of human disturbance acted as an environmental filter that selected for weedy, exotic, and wind-dispersed species regardless of forest size. Background and Objectives: Forest fragmentation can profoundly influence the long-term persistence of forests on the landscape. Habitat fragmentation can increase edge effects and limit dispersal between forest patches. In the South Gondar Administrative Zone in northern Ethiopia, many of the remaining forests are small sacred church forests governed by the Ethiopian Orthodox Tewahido Church. Materials and Methods: We examined the drivers of woody plant species composition across 46 church forests in this region, including the influence of elevation, forest size, distance between forests, human disturbance, the presence of a wall, and the importance of local/individual community forest management at the Woreda level. We also examined how dispersal syndromes are influenced by increasing distance between forests and the extent of human disturbance within forests. Results: We found that elevational zone, distance between forests, the degree of human disturbance and Woreda had the greatest effect on species composition. Forest size and the presence of a wall were not significant drivers of species composition in these forests. Conclusions: We propose connecting forests through corridors or scattered trees to increase dispersal between forests, and greater on-the-ground protection efforts to restrict people and cattle from leaving the main trails within sacred forests
\end{abstract}

Keywords: abiotic dispersal; animal dispersal; distance-decay; forest fragmentation; sacred forest; sacred grove; South Gondar Administrative Zone

\section{Introduction}

Human impacts on natural habitats are profound, with more than 50\% of Earth's land cover modified by humans [1], and $46 \%$ of the IUCN Red Listed species at risk of extinction due to land-use change [2]. Habitat fragmentation, whereby previous contiguous forest is reduced to smaller patches of forests with increasing distances between patches, is considered one of the most significant drivers of species diversity decline [3-6]. Forest fragmentation has significant and negative impacts on species richness, abundance, and diversity worldwide (Turner 1996 and citations therein, Cardelús et al. 
2019). Patterns in species composition and turnover across forest fragments provide a mechanistic understanding of community structure drivers across a landscape [7], such as whether the distance between fragments or fragment size plays a larger role. This information can inform more targeted forest management practices $[6,8]$.

Habitat fragmentation can increase disturbances in forests through the increasing degrees of edge effects, such as increased wind and temperature, decreased humidity, and decreased soil moisture [9-12]. Because the extent of edge effects increases as forest size decreases, small fragments can have a subset of the environments from large fragments made up of mostly edge habitat [13]. Forest size can, therefore, act as an environmental filter with small forests dominated by disturbance-prone species, such as weedy, exotic, or ruderal species [14,15]. The loss of core forest habitat can also lead to the loss of functional redundancy in the system [16]. For example, in Switzerland, increased cover of agricultural land reduced functional diversity by selecting for ruderal plants and generalist birds while filtering out long-lived plants, such as trees and shrubs, and birds with more forest-specific requirements, such as invertebrate feeding and tree-nesting birds [15]. In the Brazilian Atlantic forest, smaller fragments had a greater proportion of ruderal plants and plants that rely on abiotic means of dispersal, with fewer species that supply fruits for vertebrate frugivores [14].

Fragment connectivity can influence plant community composition due to differences in dispersal and pollination syndromes $[17,18]$. The distance-decay rate can be higher for plants that rely on animals for dispersal or pollination $[17,19]$. For example, the rate of decay in species similarity with increasing distance in North American spruce-fir forests was highest for animal-dispersed species (i.e., berry-fruited and nut-bearing species) than for wind-dispersed species (i.e., plumose-seeded or spore-bearing plants) [17]. In tropical forests, there is an above-average proportion of angiosperms that are dependent on animals for pollination ( $>94 \%$, Ollerton, Winfree and Tarrant 2011) and dispersal (35\%-100\%, Howe and Smallwood 1982). As a result of the high dependence of plant species on animals for dispersal and pollination, habitat fragmentation in tropical forests can have a large influence on genetic diversity as mating patterns shift towards increased selfing [20]. Thus, limited dispersal among fragments could have profound consequences for the continued persistence of fragmented forests on the landscape, particularly if within-fragment regeneration is also limited.

In the South Gondar Administrative Zone of northern Ethiopia, forests are highly fragmented. A long history of converting forests to agriculture and pasture has left a mosaic of thousands of small forest patches (1022 forests average size 5.2 ha \pm 0.44 , Cardelús et al. 2017) that are scattered across the landscape (average distance between forests is $2.1 \mathrm{~km} \pm 0.03$, Cardelús et al. 2017). These forests are sanctuaries or "arks" (sensu Laurance et al. 2012) for many plant and animal species that have almost disappeared from the region [21]. Not only are they essential refuges for biodiversity, they are also an integral component of the Ethiopian Orthodox Tewahedo Church (EOTC); in fact, the church is the reason for the long-term persistence of these patches on the landscape (at least 80 years, Scull et al. 2017). These sacred church forests are sites of prayer, community events, social gatherings, homes for religious members, and funerals [21,22]. There is reciprocity between the forests and the communities that reside in them as the community respects and protects the church forest as common property, and relies on the ecosystem services provided by the forests (shade, firewood, pollinators, cleaning air and water) [21-24]. In turn, the native taxa depend on adequate management of the forests by the community to ensure their persistence into the future [21,23-25]. The church forests are conserved through a hybrid model of protection: they are owned by the state but controlled by the EOTC and the local community [22]. Because local communities have agency over the management of church forests as found in common property models [26,27], differences in the relationship of the local community to the forest could result in variations in forest health, management, and ecosystem services provided.

Overall there is a high degree of human disturbance in these forests (56\%) as measured as the percent of the forest made up of non-native and weedy taxa, buildings, graves, trails, clearings (see Cardelús et al. 2019 for details on how this was calculated). This influences the species richness of trees and seedlings, such that forests with a high degree of disturbance from trails, buildings, and plantings 
of exotic species, have lower tree species richness, density, and biomass, and lower seedling richness and density [28]. Efforts to demarcate the church boundary and in some cases reduce disturbance from people entering the forest to gather firewood or animals to graze include the erection of a small wall around the forest $[22,29]$. Forests with walls had significantly higher seedling species richness and density but had no effect on the tree community [29]. While patterns of richness and abundance are important at highlighting trends, knowing the compositional variation can highlight species at risk and bring to focus more targeted conservation efforts.

Here we examine variations in species composition of woody plants (trees and shrubs) across 46 sacred church forests in the South Gondar region of northern Ethiopia. We examined the influence of elevation, forest size, degree of human disturbance, the presence of a wall, and the importance of local communities on forest management using Woredas, or districts, on species composition. We predicted that elevation would have a significant effect on species composition as it has affected various forest parameters such as woody species richness, tree density, and species composition [28,30]. We examined whether changes in species composition were more influenced by distance between forests (distance-decay relationships) or differences in forest sizes for all plant species and for plant species with varying dispersal syndromes. We predicted that the similarity of tree species across forests would decline with distance from each other and forest size, and that the rate of decline would vary across dispersal syndrome; we predicted that the rate of decline in similarity for animal dispersed species would be faster than for abiotic dispersed species, such as wind or ballistic as found previously [17]. If forest size acts as an environmental filter, disturbance-prone species will dominate small forests, such as weedy and exotic taxa, with few animal-dispersed long-lived species. Alternatively, the degree of human disturbance could act as the environmental filter driving differences in species composition regardless of forest size. Thus, we examined the influence of forest size and percent human disturbance on dispersal syndrome. Given previous research that walls have no significant effect on tree communities [29], we did not predict that the presence of a wall would have a large impact on plant species composition. However, we did predict that Woreda would influence plant communities because of the large role played by the local community in making forest management decisions, such as having guards, planting exotic or native species, or extracting timber or firewood by community members.

\section{Materials and Methods}

\subsection{Study Site}

Our study was conducted in afromontane forest in the South Gondar Administrative Zone in the Amhara region of Northern Ethiopia east of Lake Tana $\left(11^{\circ} 41^{\prime} 34^{\prime \prime} \mathrm{N}, 37^{\circ} 48^{\prime} 11^{\prime \prime} \mathrm{E}, 1800-2600 \mathrm{~m}\right.$ a.s.1, Figure 1). The Amhara region is mountainous (it contains Ras Dejen, the highest mountain in Ethiopia at $4550 \mathrm{~m})$ and is quite wet. The average rainfall is $1216 \mathrm{~mm}(1103-1336 \mathrm{~mm})$ and the average daily temperature is $19^{\circ} \mathrm{C}\left(16.0-23.7^{\circ} \mathrm{C}\right)$ [31]. The wet season is bimodal with most rain falling from June to September and a smaller amount in March and April [31]. Because of the topographical variation in the region, species composition varies across elevational zones. Montane forests (1800-2050 m a.s.1.) are dominated by Vernonia spp. (Asteraceae) Millettia ferruginea (Fabaceae), Maytenus senegalensis (Celastraceae), and Teclea nobilis (Rutaceae) and Upper Montane forests (2400-2800 a.s.1.) are dominated by Juniperus procera (Cupressaceae), Euphorbia abyssinica (Euphorbiaceae), Carissa edulis (Apocynaceae) and Capparis tomentosa (Capparidaceae). With permission from the office of Abune Aregawi, the Bishop of South Gondar, we established long-term research sites in 46 church forests. Twenty-two of these forests were located in the Montane zone and were within two Woredas: Dera (12 forests) and Fogera (10 forests). Twenty-four were located in the Upper Montane zone and were within three Woredas: Farta (12 forests), Esite (11 forests) and Dera (1 forest) (Figure 1). 


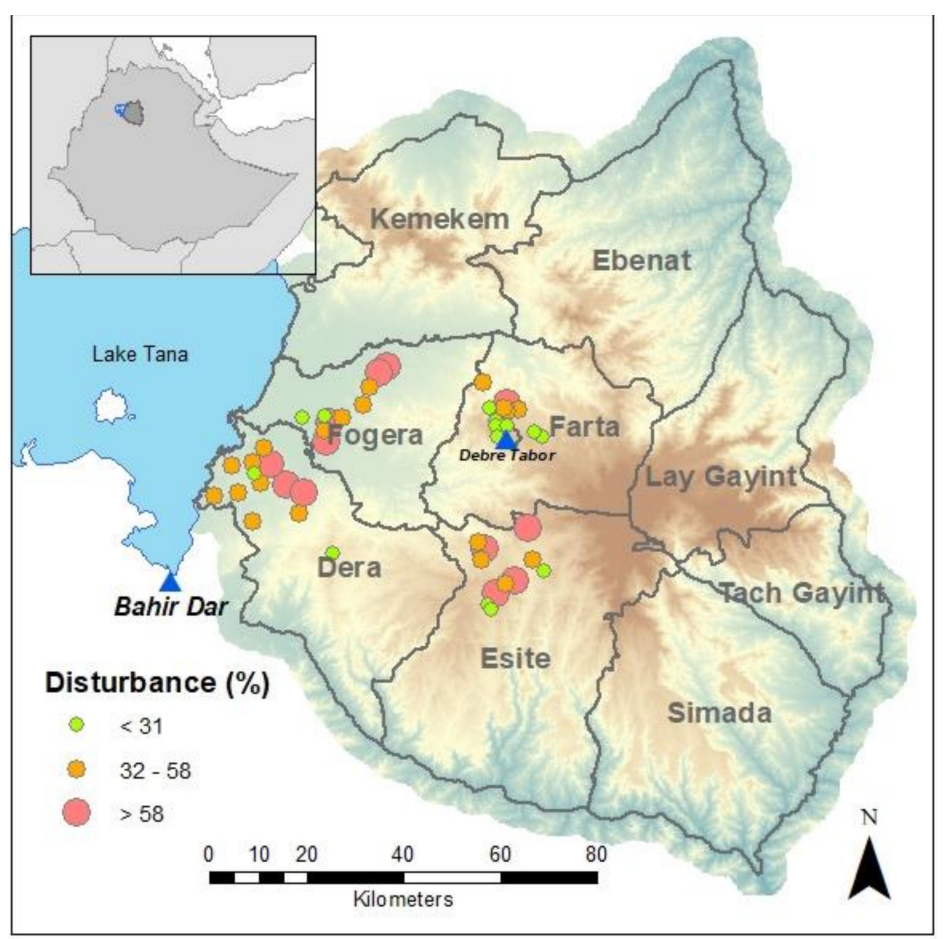

Figure 1. Map of the study area showing the distribution of the 46 church forests across four Woredas and two elevational zones. Forests in the Fogera $(n=10)$ and Dera $(n=12)$ Woredas were in the Montane elevational zone (1800-2050 a.s.l.). Forests in the Farta $(n=12)$, Dera $(n=1)$, and Esite $(n=11)$ Woredas were in the Upper Montane elevational zone (2400-2800 a.s.l.). The size and color of the dots represent the percent human disturbance (trails, clearings, buildings, and graves): $<31 \%$ (small green dots), between $32 \%-58 \%$ (medium orange dots), and $>58 \%$ (large pink dots). Basemap images obtained from ESRI.

\subsection{Survey Methods}

We surveyed all woody trees and shrubs with a diameter at breast height $(\mathrm{dbh})>1 \mathrm{~cm}$ along three modified Gentry transects that were established from the wall around the center of the church towards the edge of each forest at three cardinal directions that were $120^{\circ}$ from each other (see Figure 3 in Cardelús et al. 2019). Each transect was $2 \mathrm{~m} \times$ length of the forest, which varied quite a bit among forests $(18-350 \mathrm{~m})$. Species richness was measured as the total number of species encountered and abundance was measured as the total number of individuals counted along all three transects in each forest. For each species, we used online databases, such as Tropicos, JStor Global Plants, Kew Gardens, and the Flora of Zimbabwe to determine its fruit type and dispersal syndrome. We categorized dispersal syndrome into animal-dispersed and abiotic-dispersed plants, such as wind and ballistic.

\subsection{Statistical Analysis}

We used non-metric multidimensional scaling (NMDS) to test for differences in woody species composition between elevational zones (Montane and Upper Montane). Within each elevational zone (Montane and Upper Montane), we used NMDS to examine the effects of wall, forest size, degree of disturbance, and Woreda on tree species composition. The single forest in the Dera Woreda in the Upper Montane zone was removed as an outlier. We used the vegan package in R for our NMDS and the envfit function to test for significant effects of size and degree of disturbance [32]. For each NMDS, we used the Bray-Curtis index on abundance-based matrices. We tested for significant effects of wall and Woreda using the adonis function in the vegan package, which is a multivariate analysis of variance [32]. Degree of disturbance was calculated as the percent of each transect that was buildings, trails, graves, and clearings (for a description of disturbance types see Table 2 in Cardelús et al. 2019). 
We did not include planted taxa and weedy taxa in our measure of disturbance because these species were part of the plant community that we were analyzing. We examined patterns in dispersal syndrome among forests visually within each NMDS.

We examined differences in elevation (m), forest size (ha), species richness, \% animal-dispersed species, and \% human disturbance between Woredas in each elevational range using 2 sample t-tests to test for the influence of local community on the plant community.

Within each elevational zone (Montane and Upper Montane), we examined the relationship between similarity in species composition with distance between forests (the distance decay relationship). Similarity in species composition was calculated using a Bray-Curtis index on an abundance metric with the vegan package in $\mathrm{R}$ [32]. The great circle distance between each forest in $\mathrm{km}$ was calculated from the haversine distance using the geosphere package in $\mathrm{R}$ [33]. Pairwise comparisons in compositional similarity and geographic distance across all 46 church forests were calculated. We examined the distance-decay relationship for all plant species using linear regression, and for abiotic-dispersed species (i.e., wind, gyration or ballistic dispersal) and animal-dispersed species together using an ANCOVA. We included wind-, gyration- and ballistic-dispersed species together as one category because the species with ballistic or gyration dispersal had either small dehiscent capsules or legumes. We examined how the distance-decay relationship varied with Woreda using an ANCOVA. We examined the relationship between similarity in species composition with the percent difference in size between forests. The percent difference in size was calculated for each pairwise comparison of all forests as the absolute value of the difference between two forests (denoted in Equation (1) below as F1 and F2) divided by the average of the two numbers multiplied by 100.

$$
\frac{|F 1-F 2|}{\left(\frac{F 1+F 2}{2}\right)} * 100
$$

We examined the relationship of compositional similarity and percent difference between forests for all plant species using linear regression, for abiotic-dispersed species (i.e., wind or ballistic dispersal) and animal-dispersed species together using an ANCOVA, and within Woredas using an ANCOVA.

We used ANCOVA to examine how the percent of animal-dispersed species were influenced by percent human disturbance and size of forest across elevational zones.

\section{Results}

We found a total of 9226 individuals in 46 church forests (Table S1). We found a total of 150 species from 106 genera and 75 families with 18 unidentified species (Table S1). This was fewer than found in a previous study of 28 church forests (168 woody species $>5 \mathrm{~cm}$ dbh, Wassie et al. 2010). The most species-rich families were Fabaceae (12 species, 9 genera), Euphorbiaceae ( 6 species, 4 genera), Rubiaceae ( 5 species, 5 genera), Oleaceae ( 5 species, 3 genera), and Asteraceae ( 5 species, 3 genera). Species richness in the 46 forests ranged from 7 to 35 with an average ( \pm SE) of $18 \pm 1$ (Table S1) and abundance ranged from 16 to 558 with an average $( \pm$ SE) of $202 \pm 20$ (Table S1).

Species composition was significantly different between the Montane and Upper Montane forests (adonis, $F_{1,45}=11.75, R^{2}=0.21, p<0.001$ ). Thus, we present the results for each elevational zone separately.

\subsection{Montane Forests}

Species composition varied across church forests in the Montane zone. Species composition was significantly affected by the degree of disturbance (envfit, $\left.r^{2}=0.48, p=0.003\right)$ but not size $\left(r^{2}=0.17\right.$, $p=0.19$, Figure 2a). Wall had no significant effect on species composition (adonis, $F_{1,21}=0.52, R^{2}=0.03$, $p=0.91$ ), but species composition was significantly different between the two Woredas (adonis, $F_{1,21}=2.93, R^{2}=0.13, p=0.003$, Figure 2a). Church forests in the Fogera and Dera Woredas had similar levels of disturbance (Table 1). Average percent animal-dispersed species in forests in the Dera Woreda was significantly higher by $26 \%$ than in forests in the Fogera Woreda ( $t$-test, $t=2.78, \mathrm{df}=19, p=0.01$, 
Table 1). Species richness was also significantly higher in forests in the Dera Woreda than in the Fogera Woreda $(t$-test, $t=2.70, \mathrm{df}=20, p=0.01$, Table 1$)$.
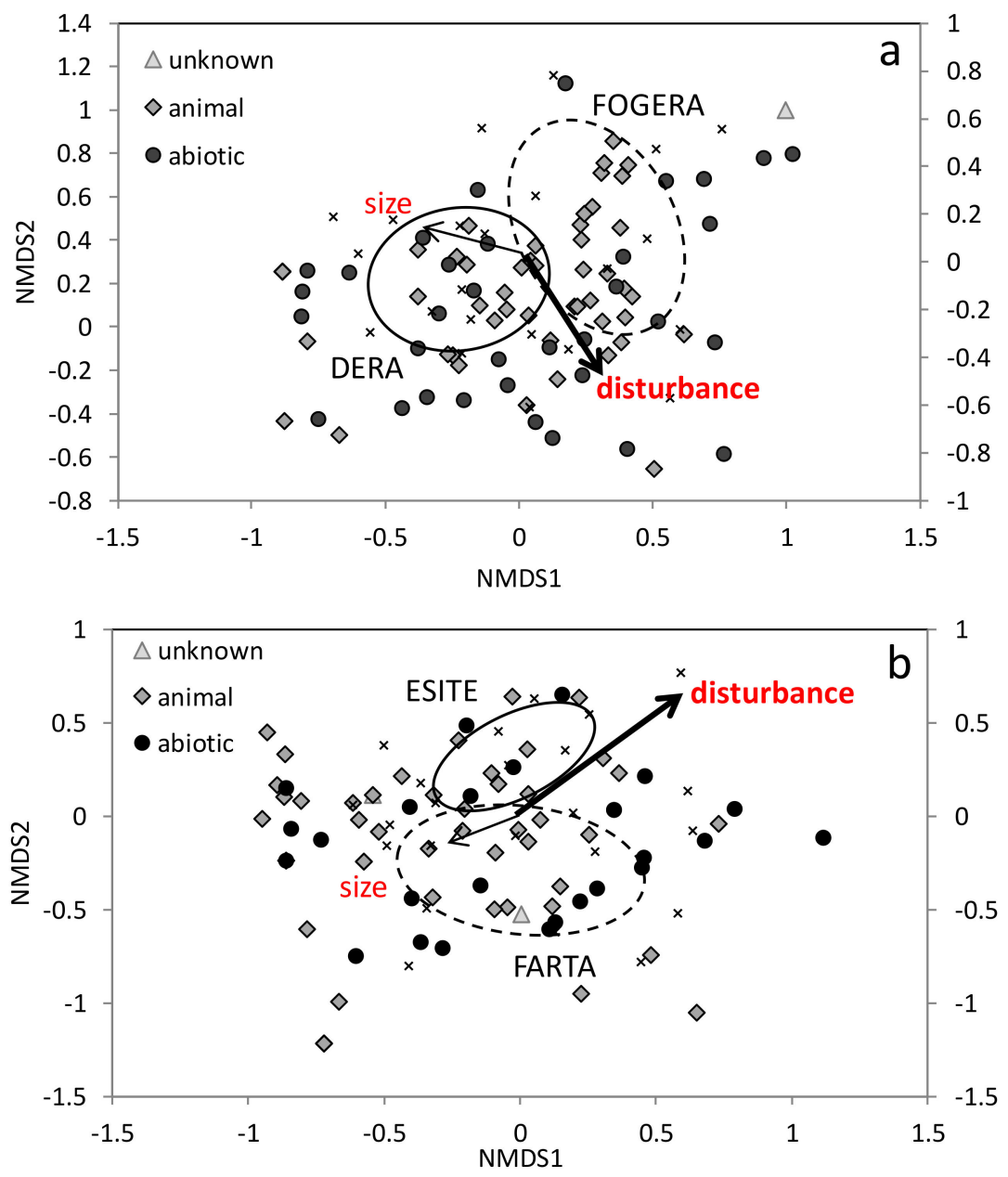

Figure 2. Non-metric multidimensional scaling ordination (NMDS) of species composition of plant species in 22 church forests in the Montane zone (a) and 23 church forests in the Upper Montane zone (b) in northern Ethiopia (the forest in the Dera Woreda in the Upper Montane zone was removed). A Bray-Curtis similarity index on abundance data was used. For a: two-dimensional stress $=0.22$, Monte Carlo stress with 1000 iterations $=0.28$. For $\mathbf{b}$ : two-dimensional stress $=0.24$, Monte Carlo stress with 1000 iterations $=0.26$. Ellipses denote the covariance matrix centered on the mean of each Woreda in each elevational range (Montane $=$ Dera and Fogera; Upper Montane $=$ Esite and Farta). Symbols represent dispersal syndromes: upward facing triangles = unknown; grey diamonds = animal dispersed species; black circles are abiotic dispersed species). Black x's represent church forests. The lines are the variables that correlated with the ordination with bold lines denoting significance.

Many of the plant species found in the most disturbed sites (those that fell negatively along NMDS axis 2 and positively along NMDS axis 1) were weedy, such as Acanthus pubescens (Acanthaceae), A. sennii (Acanthaceae) and Vernonia myriantha (Asteraceae), or exotic, such as Grevillea robusta (Proteaceae), Opuntia ficus-indica (Cactaceae), and Eucalyptus camaldulensis (Myrtaceae). Many of the plant species found in the least disturbed sites (those that fell positively along NMDS axis 2 and negatively along NMDS axis 1) were native with ranges restricted predominantly to east Africa, such as Acokanthera schimperi (Apocynaceae), Pterolobium stellatum (Fabaceae), and Euclea racemose (Ebenaceae). The three sites with the greatest disturbance that fell most negatively along NMDS axis 2 and positively along NMDS axis 1 were all in the Fogera Woreda, were less than 3.5 ha, and had $>74 \%$ disturbance. The sites with the least disturbance that fell most positively along NMDS axis 2 and negatively along NMDS axis 
1 were in the Dera Woreda, were greater than $3 \mathrm{ha}$, and had $<45 \%$ disturbance. Thus, it appears that the differences in community management of the forests across Woredas may have a large influence on species composition through the degree of disturbance.

Distance between forests had a larger effect on similarity in species composition than differences in forest size. As predicted, similarity in species composition declined significantly with distance between forests for all species $\left(F_{1,228}=49.18, p<0.001\right.$, Figure $\left.3 a\right)$ and for both abiotic-dispersed and animal-dispersed species $\left(F_{1,456}=57.6, p<0.001\right.$, Figure $\left.3 b\right)$. The distance decay relationship did not differ across dispersal syndromes $\left(F_{1,456}=2.2, p=0.14\right)$ but the rate of decline in species composition for animal-dispersed species was $50 \%$ greater than for abiotic-dispersed species $\left(F_{1,456}=73.1, p<0.001\right.$, Figure $3 b)$. Similarity in species composition declined with distance between forests significantly when considering forests only within Woredas $\left(F_{1,107}=6.4, p=0.01\right)$. The rate of decline in forests in the Fogera Woreda was steeper than in the Dera Woreda but this was not significantly different $\left(F_{1,107}=0.7\right.$, $p=0.4$, Figure 3c). Overall, similarity was significantly higher by $50 \%$ in the Dera Woreda than in the Fogera Woreda $\left(F_{1,107}=20.7, p<0.001\right.$, Figure 3c). Similarity in species composition declined significantly with percent difference in size between forests for all species $\left(F_{1,229}=4.46, p=0.04\right.$, Figure 3d) but not for abiotic-dispersed and animal-dispersed species $\left(F_{1,548}=0.9, p=0.35\right.$, Figure 3e). The way that differences in forest size influenced species similarity did not depend on dispersal syndrome $\left(F_{1,548}=2.0, p=0.16\right.$, Figure 3e), but similarity in species composition for abiotic-dispersed species was significantly larger than similarity in animal-dispersed species $\left(F_{1,548}=82.7, p<0.001\right.$, Figure 3e). Similarity in species composition was not significantly influenced by differences in forest size within Woredas $\left(F_{1,197}=0.8, p=0.4\right.$, Figure 3f).
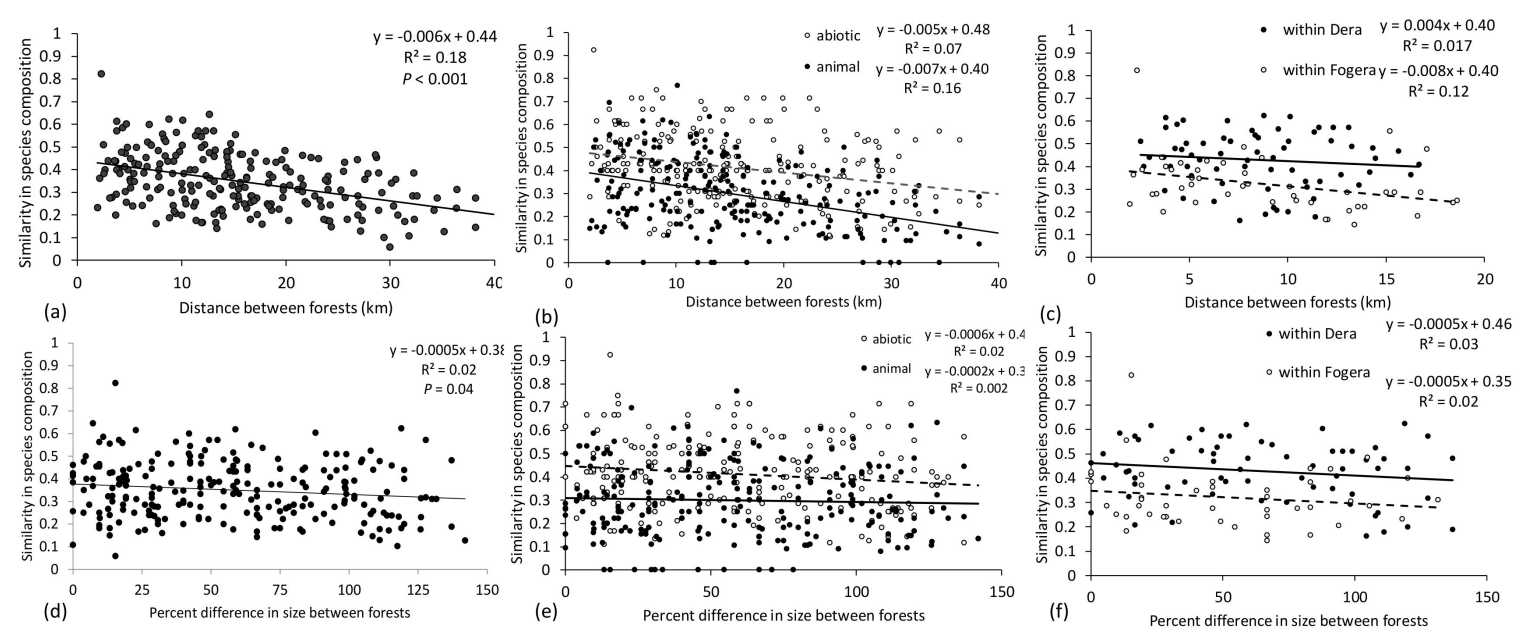

Figure 3. Similarity in woody plant species composition with distance between forests $(\mathbf{a}-\mathbf{c})$ and percent difference in size between forests (d-f) in Montane forests for all plant species (a,d), for abiotic-dispersed and animal-dispsered species $(\mathbf{b}, \mathbf{e})$, and for all species within Woredas $(\mathbf{c}, \mathbf{f})$. Similarity in species composition was calculated using a Bray-Curtis index on an abundance matrix. Distance between forests was calculated using the great circle distance from the haversine distance.

\subsection{Upper Montane Forests}

Species composition varied across sites. Wall had no significant effect on species composition (adonis, $F=1.16, R^{2}=0.05, p=0.32$ ). Species composition was significantly influenced by degree of disturbance (envfit, $r^{2}=0.60, p=0.002$ ) but not size $\left(r^{2}=0.08, p=0.43\right.$, Figure $2 b$ ). Species composition was significantly different between the two Woredas (adonis, $F=2.73, R^{2}=0.12, p=0.003$, Figure 2b). Average size of church forests in each Woreda only differed by $1.2 \%$ while church forests in the Esite Woreda had 19.5\% more human disturbance than church forests in the Farta Woreda ( $t$-test, $t=2.55$, $d f=21, p=0.02$, Table 1), which may explain the significant differences in species composition between Woredas. Average percent animal-dispersed species in forests in the Esite Woreda was not significantly 
different than in forests in the Farta Woreda ( $t$-test, $t=0.55, \mathrm{df}=21, p=0.59$, Table 1$)$. Average $( \pm \mathrm{SE})$ species richness in the Esite Woreda was not significantly different than in the Farta Woreda ( $t$-test, $t=-0.64, \mathrm{df}=21, p=0.53$, Table 1 ).

Table 1. Characteristics of each Woreda within each elevational zone. Within each elevational zone, factors were compared across Woredas using $t$-tests. Values in brackets after the Woreda are the number of church forests within each Woreda. Values with different letters between Woredas within each elevational zone denote significant differences at $p<0.05$.

\begin{tabular}{ccccccc}
\hline Elevation & Woreda & Elevation (m) & Size (ha) & Species Richness & \% Animal-Dispersed Species & \% Human Disturbance \\
\hline Montane & Dera (12) & $1897.5 \pm 18.6^{\mathrm{a}}$ & $5.4 \pm 0.9$ & $24.0 \pm 1.8^{\mathrm{a}}$ & $59.1 \pm 2.4^{\mathrm{a}}$ & $51.0 \pm 5.0$ \\
& Fogera (10) & $1842.7 \pm 11.8^{\mathrm{b}}$ & $4.4 \pm 0.8$ & $15.9 \pm 2.4^{\mathrm{b}}$ & $48.6 \pm 3.0^{\mathrm{b}}$ & $50.0 \pm 7.0$ \\
\hline \multirow{2}{*}{ Upper Montane } & Esite (11) & $2511.8 \pm 34.3$ & $6.6 \pm 2.2$ & $17.0 \pm 2.4$ & $60.0 \pm 3.2$ & $44.0 \pm 4.0^{\mathrm{a}}$ \\
& Farta (12) & $2518.3 \pm 23.2$ & $6.6 \pm 1.3$ & $19.0 \pm 2.0$ & $56.8 \pm 4.8$ & $27.0 \pm 5.0^{\mathrm{b}}$ \\
\hline
\end{tabular}

Many of the plant species found in the most disturbed sites (those that fell positively along NMDS axis 1 and NMDS axis 2) were weedy, such as Maytenus gracilipes (Celastraceae), Acanthus sennii (Acanthaceae), and Justica schimperiana (Acanthaceae), or exotic, such as Arundo donax (Poaceae) and Chenopodium album (Amaranthaceae), and most relied on abiotic means of dispersal. Many of the plant species found in the least disturbed sites were long-lived, animal-dispersed species, such as Celtis africana (Ulmaceae) and Euclea racemosa (Ebenaceae). The sites with the greatest disturbance that fell positively along NMDS axis 1 and NMDS axis 2 were both in the Esite Woreda, were $<4.3$ ha, and had $>77 \%$ disturbance. The sites that had the least disturbance were both in the Farta Woreda, were $>12.3$ ha, and had $<20 \%$ disturbance. These findings suggest that differences in species composition between Woredas might be due to differences in the degree of human disturbance.

As in Montane forests, distance between forests had a larger effect on similarity in species composition than differences in size of the forests. Similarity in species composition declined significantly with distance between all forests for all species $\left(F_{1,274}=16.70, p<0.001\right.$, Figure $\left.4 \mathrm{a}\right)$. The decline in similarity with increasing distance did not significantly vary with dispersal syndrome $\left(F_{1,548}=2.9, p=0.09\right)$ but similarity in abiotic-dispersed species was $67 \%$ higher than in animal-dispersed species $\left(F_{1,548}=84.6, p<0.001\right.$, Figure 4 b). Similarity in species composition declined with distance between forests significantly when considering forests only within Woredas $\left(F_{1,117}=3.9, p=0.05\right)$. The rate of decline in forests in the Esite Woreda was steeper than in the Fogera Woreda, but this was not significantly different $\left(F_{1,117}=3.2\right.$, $p=0.07$, Figure 4c). Overall, similarity was significantly higher in the Esite Woreda than in the Farta Woreda $\left(F_{1,117}=15.6, p<0.001\right.$, Figure $\left.4 \mathrm{c}\right)$. Similarity in species composition was not significantly influenced by percent difference in size between forests for all species $\left(F_{1,274}=0.31, p=0.58\right.$, Figure $\left.4 \mathrm{~d}\right)$ or for abiotic-dispersed species and animal-dispersed species either across all forests $\left(F_{1,548}=0.9, p=0.4\right.$, Figure $4 \mathrm{e})$ or when comparing forests within Woredas $\left(F_{1,117}=1.0, p=0.3\right.$, Figure $\left.4 \mathrm{f}\right)$. There was significantly higher similarity in abiotic-dispersed species than in animal-dispersed species across all forests $\left(F_{1,548}=82.7, p<0.001\right.$, Figure $\left.4 \mathrm{e}\right)$. Similarity in species composition was significantly higher within forests in the Esite Woreda than in the Farta Woreda $\left(F_{1,117}=7.9, p=0.006\right.$, Figure $\left.4 \mathrm{f}\right)$.

\subsection{All Forests}

The percent of animal-dispersed species in all church forests declined significantly with increasing human disturbance (ANCOVA, $F_{1,42}=19.42, p<0.001$, Figure 5) but it did not depend on elevational zone (ANCOVA, $F_{1,42}=0.13, p=0.72$ ). Elevational zone had no significant effect on the percent of animal-dispersed species (ANCOVA, $F_{1,42}=0.58, p=0.45$ ). The percent of animal-dispersed species in all church forests was not significantly influenced by forest size (ANCOVA, $F_{1,42}=2.74, p=0.11$ ) or the interaction of size and elevation (ANCOVA, $F_{1,42}=1.42, p=0.24$ ). 

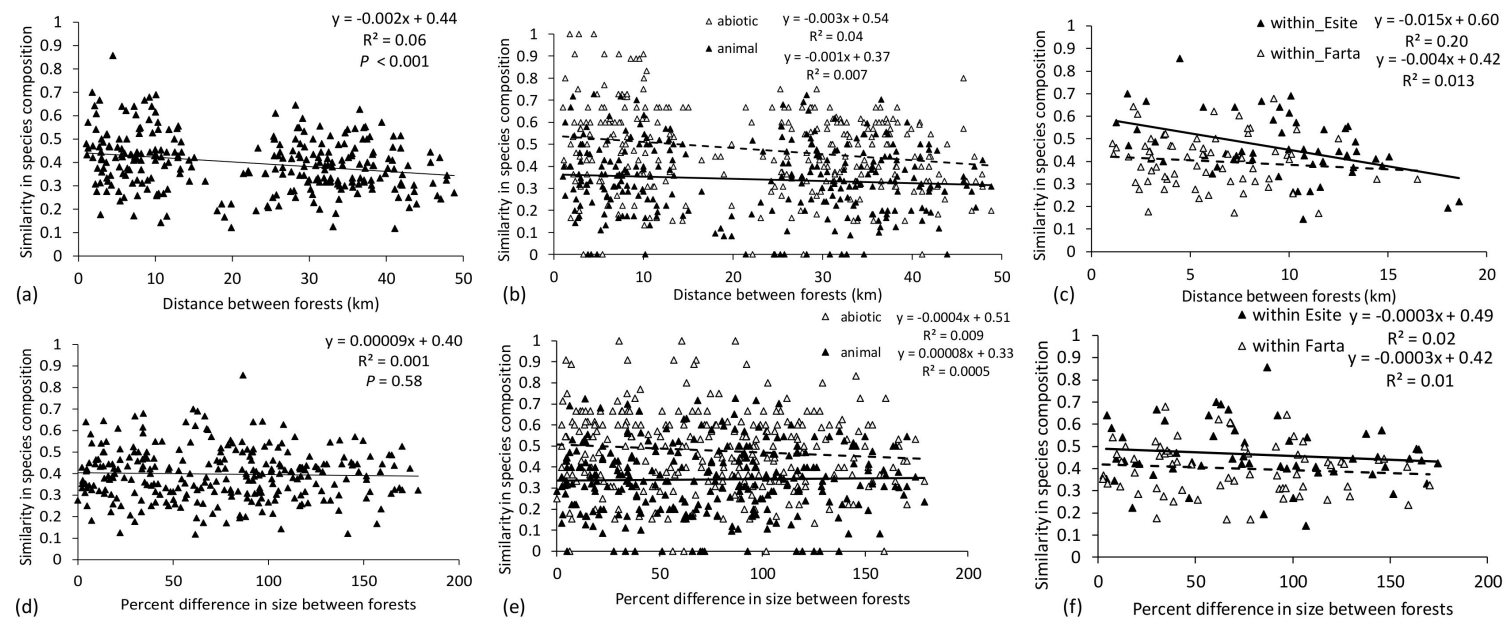

Figure 4. Similarity in woody plant species composition with distance between forests $(\mathbf{a}-\mathbf{c})$ and percent difference in size between forests (d-f) in Upper Montane forests for all plant species $(\mathbf{a}, \mathbf{d})$, for abioticdispersed and animal-dispersed species (b,e), and for all species within Woredas (c,f). Similarity in species composition was calculated using a Bray-Curtis index on an abundance matrix. Distance between forests was calculated using the great circle distance from the haversine distance.

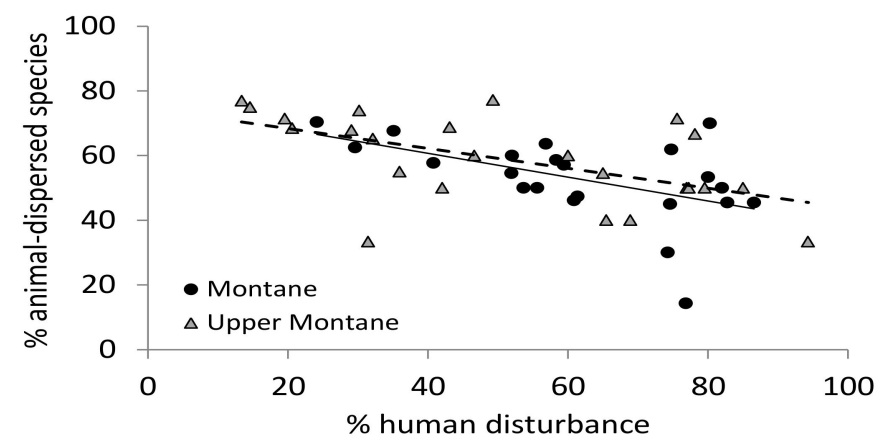

Figure 5. Linear regression of percent human disturbance on percentage of animal-dispersed species in each sacred church forest in the Montane zone $\left(n=22 ; \mathrm{y}=-0.37 \mathrm{x}+75.43, R^{2}=0.26\right.$; solid line, black circles) and Upper Montane zone ( $n=24 ; \mathrm{y}=-0.31 \mathrm{x}+74.52, R^{2}=0.31$; dashed line, grey diamonds $)$ in the South Gondar Administrative Zone in northern Ethiopia.

\section{Discussion}

Species composition among 46 church forests at both elevational ranges was more influenced by degree of human disturbance than any other factor we examined. Interestingly, we found little support that forest size influenced species composition. Given that $93 \%$ of forests in the South Gondar region are $<15$ ha [28], the small variations we found in forest size might not be large enough to affect species composition. We found no significant effect of a wall, which was not surprising as previous research found only seedlings affected by the presence of a wall [29]. The differences we found between Woredas at each elevational range suggests that differences in the degree of human presence or the relationship of the local community to the forests between districts could be driving variations in species composition. Our data support our alternative hypothesis that the degree of human disturbance acts as an environmental filter affecting plant communities regardless of size.

We found a significant decline in species compositional similarity among forests with increasing distance between forests but not with varying forest size. This means that plant communities become more dissimilar to each other as distance between them increases but not as differences in forest sizes between them increase. Our findings are in alignment with a study of 28 church forests in the South Gondar Administrative Zone, that also found that similarity in species composition decreased with 
increasing distance between forests [30]. In the Montane region, the decline in species compositional similarity was more rapid for animal-dispersed plants than for abiotic-dispersed plants, which suggests that plants that rely on animals for dispersal are more dispersal limited among these forests than windor ballistic-dispersed plants [17]. The steeper slope for animal-dispersed plants than abiotic-dispersed plants suggests that they are more aggregated, which might be due to their lower dispersal distances or a declining disperser community [17,34]. Surprisingly, in the Upper Montane zone, the decline in similarity for abiotic-dispersed plants was faster than for animal-dispersed plants. The Upper Montane zone is more mountainous than the Montane zone, which could disrupt wind currents between forests [35]. The lack of a significant decline in animal-dispersed species with increasing distance suggests that the animals that are present may be able to disperse to forests up to $50 \mathrm{~km}$ away. However, the decline in animal-dispersed plants with increasing human disturbance in the Upper Montane zone indicates that these dispersal agents avoid forests with a large human presence. In northeastern Tanzania, the most effective seed removal agents, which included three local bird species, removed $24 \%-85 \%$ fewer seeds from forest fragments (size range of 2-31 ha) than continuous forest (3500 ha) [36], which suggests that the dispersal agents that can facilitate dispersal of the core tree species might avoid forest fragments if they are mostly edge habitat. Furthermore, these fragments were not sacred forests or sites with a permanent human population; thus, dispersal of plants by animals in Ethiopian's church forests where there is a continuous human presence could be even further reduced if the dispersal agents avoid areas with a large human presence. Evidence is seen in the significant decline in animal-dispersed plants with increasing human disturbance regardless of elevational zone.

These church forests are the remaining arks for many indigenous species in the region and provide invaluable services to the church community. The reduced number of animal-dispersed species as human presence increases is alarming, particularly given the decline in forest area in the matrix around these church forests [37] and the high percentage of plant species that rely on animals for dispersal and pollination in tropical forests $[38,39]$. With reduced pollination due to habitat fragmentation in tropical forests, plants have shifted to increased selfing [20], which could compromise the continued persistence of fragmented forests on the landscape and reduce adaptation potential of these species to changes in their environment. The other possible source of forest regeneration is in the seed bank. However, few woody species have been recorded in Ethiopia's sacred church forests seed banks [25,40], which indicates that their presence in the forest is necessary to ensure future persistence of these woody species and that active restoration efforts are needed to conserve seeds and begin a native tree seedling planting program.

The two Woredas in the Montane zone that we surveyed were Dera and Fogera. Both of these Woredas border lake Tana, but Dera is closer to Bahir Dar, a medium sized city (243,330, [41]). The church forests in the Dera Woreda had higher species richness, a greater percentage of animal-dispersed species, and greater similarity in species composition among forests than the church forests in the Fogera Woreda. Given that distance from population center was not found to significantly affect these church forest plant communities [28], other factors between these Woredas must drive variations in plant communities. In the Upper Montane zone, church forest species composition also varied across Woredas. Forests in the Esite Woreda are closer to Debre Tabor, a small city $(87,100$, [28]), and had greater disturbance than forests in the Farta Woreda, which suggests that the influence of proximity to population centers differs across elevational zones. Given that forests within each zone experience similar microclimates and environmental conditions, socio-ecological factors likely differ across these Woredas and drive the variations in species composition, which could be informative to future forest conservation efforts. In a study examining community perspectives of church forest use in four church forests across four Woredas in 2002 and 2014 in the South Gondar Administrative Zone, respondents showed a lot of variation in their perceptions of the ecological and social values across Woredas, and there were shifts from social responsibility to official responsibility in protecting the forest and from valuing church laws to valuing state laws [42]. In ethnographic surveys of church forest communities in the South Gondar region, head priests varied in their understanding of why the church forest exists [27]. 
Good governance and strong leadership can allow for strong social capital, or effective community interactions, such as knowledge sharing among community members [43], which can strengthen effective community-based land management [44]. Thus, variation in governance and leadership as well as perceptions of the value of the church forest could explain the differences in species composition between Woredas within each elevational zone. Further understanding of perceptions of the value of forests and motivations to protect and manage the forest by local stakeholders across Woredas and elevational zones is needed.

Despite the largely negative impact of anthropogenic land-use change for many plants and large animals, a mosaic of forest with pastoral and agricultural land can provide habitat for small-mammals and a diverse array of plant species [45]. The ability of plant species to cross the matrix varies by species and the make-up of the matrix (e.g., agriculture, towns, roads), which indicates that distance alone cannot determine which species are most affected by fragmentation and that modification of the matrix can reduce the extinction risk of species in fragments [46]. In a large-scale analysis examining the importance of protected areas in tropical forests in conserving biodiversity globally, large frugivorous birds were deemed less vulnerable to the effects of fragmentation than other groups [47]. This analysis also found that reserves with increased on-the-ground protection efforts were improving in health due to the reduction in deforestation, logging, and hunting in the reserves [47]. Declining forest cover around the reserves was also contributing greatly to reduced forest health [47]. Given that the forest cover and scattered trees around church forests in Ethiopia have declined in the last century [37], building corridors and planting trees between forests would be a fruitful area to ensure connectivity between forests to conserve both species diversity and genetic diversity of the sacred church forests [48]. The global analysis by Laurance et al. (2012) found that changing climatic conditions, such as precipitation, temperature and wind, had weaker effects on forest reserve health than anthropogenic disturbances, such as logging and hunting [47]. This is a positive outcome, as it suggests that shifts in human values and behavioral norms within communities could help preserve forest integrity regardless of the changing climate.

We suggest several avenues to maintain and restore church forests. Building corridors using scattered native trees could improve animal movement and connectivity among forests for animal-dispersed plants [19] as well as improve forest health by modulating/buffering edge effects [47]. While forest size had little effect on species composition, larger forests will have fewer edge effects, and so we also recommend increasing core forest areas by planting native trees along the forest edge. We do not recommend planting Eucalyptus, which some forests have done, as it degrades soil nutrients and compromises native forest regeneration [49]. In a study examining the success of facilitated regeneration in Ethiopian church forests, seedlings of four native tree species grew well along the edge; these species can be used to increase core forest area [31]. To reduce the degree of human disturbance, we suggest on-the-ground protection efforts, such as continued building of stone walls and guards both of which encourage cattle and people to enter the forest using few main trails. The presence of guards may be less effective, as their main job is protecting the church and its valuables, which keeps them by the inner wall of the church and not on the periphery of the forest [22,27]. Thus, we propose guards whose sole role is to protect the forest. For any of these recommendations to take root, however, they need to be in line with community traditions [24] and include indigenous narratives of protection [27] as any recommendations or programs initiated outside of the culture of the church community will likely not succeed [50,51].

Supplementary Materials: The following are available online at http://www.mdpi.com/1999-4907/11/10/1082/s1, Table S1: List of woody species and their characteristics, Table S2: Sacred church forests and their characteristics.

Author Contributions: Conceptualization, C.L.C., C.L.W. and P.S.; methodology, C.L.C., C.L.W., and P.S.; formal analysis, C.L.W.; investigation, C.L.C., C.L.W., A.B.M., M.B-S., R.T. and P.S.; resources, C.L.C. and B.A.T.; data curation, C.L.W. and C.L.C..; writing-original draft preparation, C.L.W..; writing-review and editing, A.B.M., M.B-S., R.T., and C.L.C.; visualization, C.L.W.; supervision, C.L.C. and B.A.T.; project administration, C.L.C.; funding acquisition, C.L.C., C.L.W. and P.S. All authors have read and agreed to the published version of the manuscript. 
Funding: This work was funded through the Dynamics of Coupled Natural Human Ecosystems Program of the National Science Foundation Award No. 1518501. Initial work was funded by The Picker Interdisciplinary Science Institute at Colgate University: http://www.colgate.edu/centers-and-institutes/picker-interdisciplinary-scienceinstitute.

Acknowledgments: We thank Abune Aregawi, the Bishop of South Gondar, for kindly granting us permission to work in the church forests. We are very grateful to the EOTC respected church priests, monks, and the local community for kindly welcoming us into the forests and sometimes helping us with plant identification or other field work. The authors thank K. Bazany, K. Jenson, Z M. Isrealit, and S. Hewitt for assistance in the field, Bahir Dar University for logistical support, and two anonymous reviewers for helpful comments that improved the manuscript.

Conflicts of Interest: The authors declare no conflict of interest.

\section{References}

1. Ecosystems and Human Well-Being-Synthesis: A Report of the Millenium Ecosystem Assessment; Island Press: Washington, DC, USA, 2005.

2. The IUCN Red List of Threatened Species; IUCN: Gland, Switzerland, 2004.

3. Tilman, D.; May, R.M.; Lehman, C.L.; Nowak, M.A. Habitat destruction and the extinction debt. Nature 1994, 371, 65-66. [CrossRef]

4. Foley, J.A.; Defries, R.; Asner, G.P.; Barford, C.; Bonan, G.; Carpenter, S.R.; Chapin, F.S.; Coe, M.T.; Daily, G.C.; Gibbs, H.K.; et al. Global consequences of land use. Science 2005, 309, 570-574. [CrossRef]

5. Eriksson, O.; Ehrlén, J. Landscape fragmentation and the viability of plant populations. In Integrating Ecology and Evolution in a Spatial Conect: 14th Special Symposium of the British Ecological Society; Silvertown, K., Antonovics, J., Eds.; Cambridge University Press: Cambridge, UK, 2001; pp. 157-176.

6. Haddad, N.M.; Brudvig, L.A.; Clobert, J.; Davies, K.F.; Gonzalez, A.; Holt, R.D.; Lovejoy, T.E.; Sexton, J.O.; Austin, M.P.; Collins, C.D.; et al. Habitat fragmentation and its lasting impact on Earth's ecosystems. Sci. Adv. 2015, 1, e1500052. [CrossRef]

7. Jacquemyn, H.; Butaye, J.; Dumortier, M.; Hermy, M.; Lust, N. Effects of age and distance on the composition of mixed deciduous forest fragments in an agricultural landscape. J. Veg. Sci. 2001, 12, 635-642. [CrossRef]

8. Turner, I.M. Species Loss in Fragments of Tropical Rain Forest: A Review of the Evidence. J. Appl. Ecol. 1996, 33, 200. [CrossRef]

9. Woodroffe, R.; Ginsberg, J.R. Edge Effects and the Extinction of Populations Inside Protected Areas. Science 1998, 280, 2126-2128. [CrossRef]

10. Laurance, W.F.; Camargo, J.L.C.; Luizão, R.C.C.; Laurance, S.G.; Pimm, S.L.; Bruna, E.M.; Stouffer, P.C.; Bruce Williamson, G.; Benítez-Malvido, J.; Vasconcelos, H.L.; et al. The fate of Amazonian forest fragments: A 32-year investigation. Biol. Conserv. 2011, 144, 56-67. [CrossRef]

11. Lovejoy, T.E.; Bierragaard, R.O.; Rylands, A.B.; Malcolm, J.R.; Quintela, C.E.; Harper, L.H.; Brown, K., Jr. Edge and other effect of isolation on Amazon forest fragments. In Conservation Biology: The Science of Scarcity and Diversity; Powell, A.H., Powell, G.V.N., Shubart, H.O.R., Soule, M.E., Eds.; Sinauer: Sunderland, MA, USA, 1986; pp. 257-285.

12. Kapos, V. Effects of isolation on the water Island Press. In Ecosystems and Human Well-Being-Synthesis: A Report of the Millenium Ecosystem Assessment; Island Press: Washington, DC, USA, 2005.

13. Malcolm, J.R. Edge Effects in Central Amazonian Forest Fragments. Ecology 1994, 75, 2438-2445. [CrossRef]

14. Tabarelli, M.; Mantovani, W.; Peres, C.A. Effects of habitat fragmentation on plant guild structure in the montane Atlantic forest of southeastern Brazil. Biol. Conserv. 1999, 91, 119-127. [CrossRef]

15. Concepción, E.D.; Götzenberger, L.; Nobis, M.P.; de Bello, F.; Obrist, M.K.; Moretti, M. Contrasting trait assembly patterns in plant and bird communities along environmental and human-induced land-use gradients. Ecography 2017, 40, 753-763. [CrossRef]

16. Flynn, D.F.B.; Gogol-Prokurat, M.; Nogeire, T.; Molinari, N.; Richers, B.T.; Lin, B.B.; Simpson, N.; Mayfield, M.M.; DeClerck, F. Loss of functional diversity under land use intensification across multiple taxa. Ecol. Lett. 2009, 12, 22-33. [CrossRef] [PubMed]

17. Nekola, J.C.; White, P.S. The distance decay of similarity in biogeography and ecology. J. Biogeogr. 1999, 26, 867-878. [CrossRef] 
18. Aguilar, R.; Ashworth, L.; Galetto, L.; Aizen, M.A. Plant reproductive susceptibility to habitat fragmentation: Review and synthesis through a meta-analysis. Ecol. Lett. 2006, 9, 968-980. [CrossRef] [PubMed]

19. Kormann, U.; Scherber, C.; Tscharntke, T.; Klein, N.; Larbig, M.; Valente, J.J.; Hadley, A.S.; Betts, M.G. Corridors restore animal-mediated pollination in fragmented tropical forest landscapes. Proc. R. Soc. B Biol. Sci. 2016, 283, 20152347. [CrossRef] [PubMed]

20. Aguilar, R.; Quesada, M.; Ashworth, L.; Herrerias-Diego, Y.; Lobo, J. Genetic consequences of habitat fragmentation in plant populations: Susceptible signals in plant traits and methodological approaches. Mol. Ecol. 2008, 17, 5177-5188. [CrossRef]

21. Wassie, A. Opportunities, Constraints, and Propects of the Ethiopian Orthodox Tewahido Churches in Conserving Forest Resources: The Case of Churches in South Gondar, Northern Ethiopia; Swedish University of Agricultural Sciences: Uppsala, Sweden, 2002.

22. Klepeis, P.; Orlowska, I.A.; Kent, E.F.; Cardelús, C.L.; Scull, P.; Wassie Eshete, A.; Woods, C. Ethiopian Church Forests: A Hybrid Model of Protection. Hum. Ecol. 2016, 44. [CrossRef]

23. Cardelús, C.L.; Scull, P.; Wassie Eshete, A.; Woods, C.L.; Klepeis, P.; Kent, E.; Orlowska, I. Shadow conservation and the persistence of sacred church forests in northern Ethiopia. Biotropica 2017, 49, 726-733. [CrossRef]

24. Bongers, F.J.J.M.; Wassie, A.; Sterck, F.J.; Ayele, T.B.; Teketay, D. Ecological restoration and church forests in northern Ethiopia. J. Drylands 2006, 1, 35-44.

25. Teketay, D.; Granström, A. Soil seed banks in dry Afromontane forests of Ethiopia. J. Veg. Sci. 1995, 6, 777-786. [CrossRef]

26. McKean, M.A.; Ostrom, E. Common property regimes in the forest: Just a relic from the past. Unasylva 1995, 180, 3-15.

27. Orlowska, I.; Klepeis, P. Ethiopian church forests: A socio-religious conservation model under change. J. East. Afr. Stud. 2018, 12, 674-695. [CrossRef]

28. Cardelús, C.L.; Woods, C.L.; Bitew Mekonnen, A.; Dexter, S.; Scull, P.; Tsegay, B.A. Human disturbance impacts the integrity of sacred church forests, Ethiopia. PLOS ONE 2019, 14, e0212430. [CrossRef]

29. Woods, C.L.; Cardelús, C.L.; Scull, P.; Wassie, A.; Baez, M.; Klepeis, P. Stone walls and sacred forest conservation in Ethiopia. Biodivers. Conserv. 2017, 26, 209-221. [CrossRef]

30. Wassie, A.; Sterck, F.J.; Bongers, F. Species and structural diversity of church forests in a fragmented Ethiopian Highland landscape. J. Veg. Sci. 2010, 21, 938-948. [CrossRef]

31. Wassie, A.; Sterck, F.J.; Teketay, D.; Bongers, F. Tree Regeneration in Church Forests of Ethiopia: Effects of Microsites and Management. Biotropica 2009, 41, 110-119. [CrossRef]

32. Oksanen, J.; Guillaume Blanchert, F.; Kindt, R.; Legendre, P.; O’Hara, B.; Simpson, G.L.; Solymos, P.; Stevens, M.H.H.; Wagner, H.; Vegan: Community Ecology Package. R Packag, Version 1.17-9. 2010. Available online: http://CRAN.R-project.org/package=vegan. (accessed on 1 September 2009).

33. Hijmans, R.J.; Geosphere: Spherical Trigonometry. R Package Version 1.5-10. 2019. Available online: https://CRAN.R-project.org/package=geosphere. (accessed on 15 March 2020).

34. Morlon, H.; Chuyong, G.; Condit, R.; Hubbell, S.; Kenfack, D.; Thomas, D.; Valencia, R.; Green, J.L. A general framework for the distance-decay of similarity in ecological communities. Ecol. Lett. 2008, 11, 904-917. [CrossRef]

35. Banta, R.M.; Berri, G.; Blumen, W.; Carruthers, D.J.; Dalu, G.A.; Durran, D.R.; Egger, J.; Garratt, J.R.; Hanna, S.R.; Hunt, J.C.R.; et al. The Role of Mountain Flows in Making Clouds. In Atmospheric Processes Over Complex Terrain; American Meteorological Society: Boston, MA, USA, 1990; pp. 229-283.

36. Cordeiro, N.J.; Ndangalasi, H.J.; McEntee, J.P.; Howe, H.F. Disperser limitation and recruitment of an endemic African tree in a fragmented landscape. Ecology 2009, 90, 1030-1041. [CrossRef]

37. Scull, P.; Cardelús, C.L.; Klepeis, P.; Woods, C.L.; Frankl, A.; Nyssen, J. The Resilience of Ethiopian Church Forests: Interpreting Aerial Photographs, 1938-2015. Land Degrad. Dev. 2017, 28. [CrossRef]

38. Ollerton, J.; Winfree, R.; Tarrant, S. How many flowering plants are pollinated by animals? Oikos 2011, 120, 321-326. [CrossRef]

39. Howe, H.F.; Smallwood, J. Ecology of Seed Dispersal. Annu. Rev. Ecol. Syst. 1982, 13, 201-228. [CrossRef]

40. Wassie, A.; Teketay, D. Soil seed banks in church forests of northern Ethiopia: Implications for the conservation of woody plants. Flora Morphol. Distrib. Funct. Ecol. Plants 2006, 201, 32-43. [CrossRef]

41. Brinkhoff, T. City Population. Available online: http://www.citypopulation.de/Ethiopia.html (accessed on 10 October 2020). 
42. Reynolds, T.W.; Stave, K.A.; Sisay, T.S.; Eshete, A.W. Changes in community perspectives on the roles and rules of church forests in northern Ethiopia: Evidence from a panel survey of four Ethiopian Orthodox Communities. Int. J. Commons 2017, 11, 355-387. [CrossRef]

43. Wilson, G.A. Community Resilience and Environmental Transitions; Taylor and Francis: Milton Park, UK, 2012; ISBN 9780203144916.

44. Bebbington, A.; Perreault, T. Social Capital, Development, and Access to Resources in Highland Ecuador. Econ. Geogr. 1999, 75, 418. [CrossRef]

45. Graham, S.I.; Kinnaird, M.F.; O’Brien, T.G.; Vågen, T.; Winowiecki, L.A.; Young, T.P.; Young, H.S. Effects of land-use change on community diversity and composition are highly variable among functional groups. Ecol. Appl. 2019, 29. [CrossRef]

46. Ricketts, T.H. The matrix matters: Effective isolation in fragmented landscapes. Am. Nat. 2001, 158, 87-99. [CrossRef] [PubMed]

47. Laurance, W.F.; Carolina Useche, D.; Rendeiro, J.; Kalka, M.; Bradshaw, C.J.A.; Sloan, S.P.; Laurance, S.G.; Campbell, M.; Abernethy, K.; Alvarez, P.; et al. Averting biodiversity collapse in tropical forest protected areas. Nature 2012, 489, 290-294. [CrossRef]

48. Couvet, D. Deleterious Effects of Restricted Gene Flow in Fragmented Populations. Conserv. Biol. 2002, 16, 369-376. [CrossRef]

49. Cardelús, C.L.; Mekonnen, A.B.; Jensen, K.H.; Woods, C.L.; Baez, M.C.; Montufar, M.; Bazany, K.; Tsegay, B.A.; Scull, P.R.; Peck, W.H. Edge effects and human disturbance influence soil physical and chemical properties in Sacred Church Forests in Ethiopia. Plant Soil 2020, 1-14. [CrossRef]

50. Bhagwat, S.A.; Rutte, C. Sacred groves: Potential for biodiversity management. Front. Ecol. Environ. 2006, 4, 519-524. [CrossRef]

51. Hayes, T.M. Parks, People, and Forest Protection: An Institutional Assessment of the Effectiveness of Protected Areas. World Dev. 2006, 34, 2064-2075. [CrossRef]

(C) 2020 by the authors. Licensee MDPI, Basel, Switzerland. This article is an open access article distributed under the terms and conditions of the Creative Commons Attribution (CC BY) license (http://creativecommons.org/licenses/by/4.0/). 